\title{
A biochemical comparison of alclofenac and D-penicillamine in rheumatoid arthritis
}

\author{
H. A. BIRD, J. S. DIXON, M. E. PICKUP, M. R. LEE, AND V. WRIGHT \\ From the Clinical Pharmacology Unit, Royal Bath Hospital, Harrogate, and University Department of Medi- \\ cine, General Infirmary, Leeds
}

SUMMARY In view of the claim that alclofenac has a specific antirheumatoid action a detailed biochemical study has been made over a 6-month period of 2 groups of patients with rheumatoid arthritis receiving either alclofenac or D-penicillamine for the first time. We found no biochemical evidence and little clinical evidence that alclofenac had a 'penicillamine-like' effect in rheumatoid arthritis.

Alclofenac* (4-allyloxyl-3-chlorophenylacetic acid) is a nonsteroidal anti-inflammatory agent derived from arylacetic acid. Biochemical studies have suggested, however, that this drug may have a more specific action in rheumatoid arthritis, fundamentally influencing the disease process. This evidence comes from fall in erythrocyte sedimentation rate (ESR), 1,2 fall in immunoglobulins and latex agglutination titre but not in sheep cell agglutination test (SCAT) titre ${ }^{3}$ rise in free plasma tryptophan, ${ }^{1}$ and a rise in serum sulphydryl levels. ${ }^{4}$

As part of a long-term study in which we are attempting to define biochemical profiles of response in patients with rheumatoid arthritis treated for the first time with 'specific' drugs we have compared the majority of these biochemical changes in patients treated either with D-penicillamine or with alclofenac. We report these results, which are at variance with those previously described.

\section{Patients and methods}

All patients had classical or definite rheumatoid arthritis (American Rheumatism Association criteria) and moderate or severe disease activity judged by the presence of at least 3 out of: (i) tenderness of 6 joints or more; (ii) swelling of more than 3 joints; (iii) morning stiffness $>45$ minutes; (iv) articular index ${ }^{5}>20$; (v) ESR $>28 \mathrm{~mm} / \mathrm{h}^{1}$ Patients who had received gold, D-penicillamine, hydroxychloroquine, immunosuppressive drugs, or

Accepted for publication 5 June 1979

Correspondence to Dr H. A. Bird, Clinical Pharmacology Unit, Royal Bath Hospital, Cornwall Road, Harrogate, North Yorkshire HG1 2PS.

*This drug is now discontinued. alclofenac at any stage before were excluded, though patients on steady-state steroid therapy were allowed.

After a 2 week washout period on Nu-seals Aspirin $900 \mathrm{mg}$ qds alone to establish clinical and biochemical baselines, patients were allocated either to alclofenac $1.0 \mathrm{~g}$ tds (15 patients) or $\mathrm{D}$ penicillamine $125 \mathrm{mg} /$ day increasing to $500 \mathrm{mg} /$ day by week 8 and thereafter (15 patients). Nu-seals Aspirin, taken as required, was the only other drug allowed. Patients were seen at weeks $-2,0,2,4$, $8,12,16,20$, and 24 .

Eighteen biochemical and 6 immunological assessments, performed at each visit included erythrocyte sedimentation rate, plasma viscosity, ${ }^{6} \mathrm{C}$ reactive protein, ${ }^{7}$ total serum sulphydryl levels, ${ }^{8}$ immunoglobulins, and rheumatoid factor (latex fixation and SCAT).

Clinical assessments performed at each visit were pain score (1-5 scale each night), summated change scale, ${ }^{9}$ duration of early morning stiffness, articular index, ${ }^{5}$ grip strength, joint circumference (arthrocircometcr), functional grade (1-5 scale), and return aspirin count.

Correlation matrices were constructed between clinical variables and the 18 biochemical variables for both D-penicillamine and alclofenac. Each biochemical variable was correlated (Pearson correlation) in turn with each clinical variable, mean figures at each of the 8 clinic visits being used.

\section{Results}

Fourteen out of 15 patients completed 24 weeks of D-penicillamine treatment, one withdrawing with a skin rash. Nine out of 15 patients completed 24 
weeks of alclofenac treatment. Reasons for withdrawal were skin rash 2 , lack of effect 1 , noncompliance 2 , and severe diarrhoea apparently induced by alclofenac in a seropositive patient 1 .

The majority of biochemical variables showed significant improvement with D-penicillamine but not with alclofenac. Fig. 1 shows changes in erythrocyte sedimentation rate, plasma viscosity,
C-reactive protein, and total serum sulphydryl levels for the 2 drugs. Levels of significance of changes from baseline values are also shown. Of the immunological tests carried out IgM was the only parameter to change with D-penicillamine therapy, though its fall did not reach a level of statistical significance. No significant change was seen in immunoglobulins or SCAT titre in the alclofenac treated group.
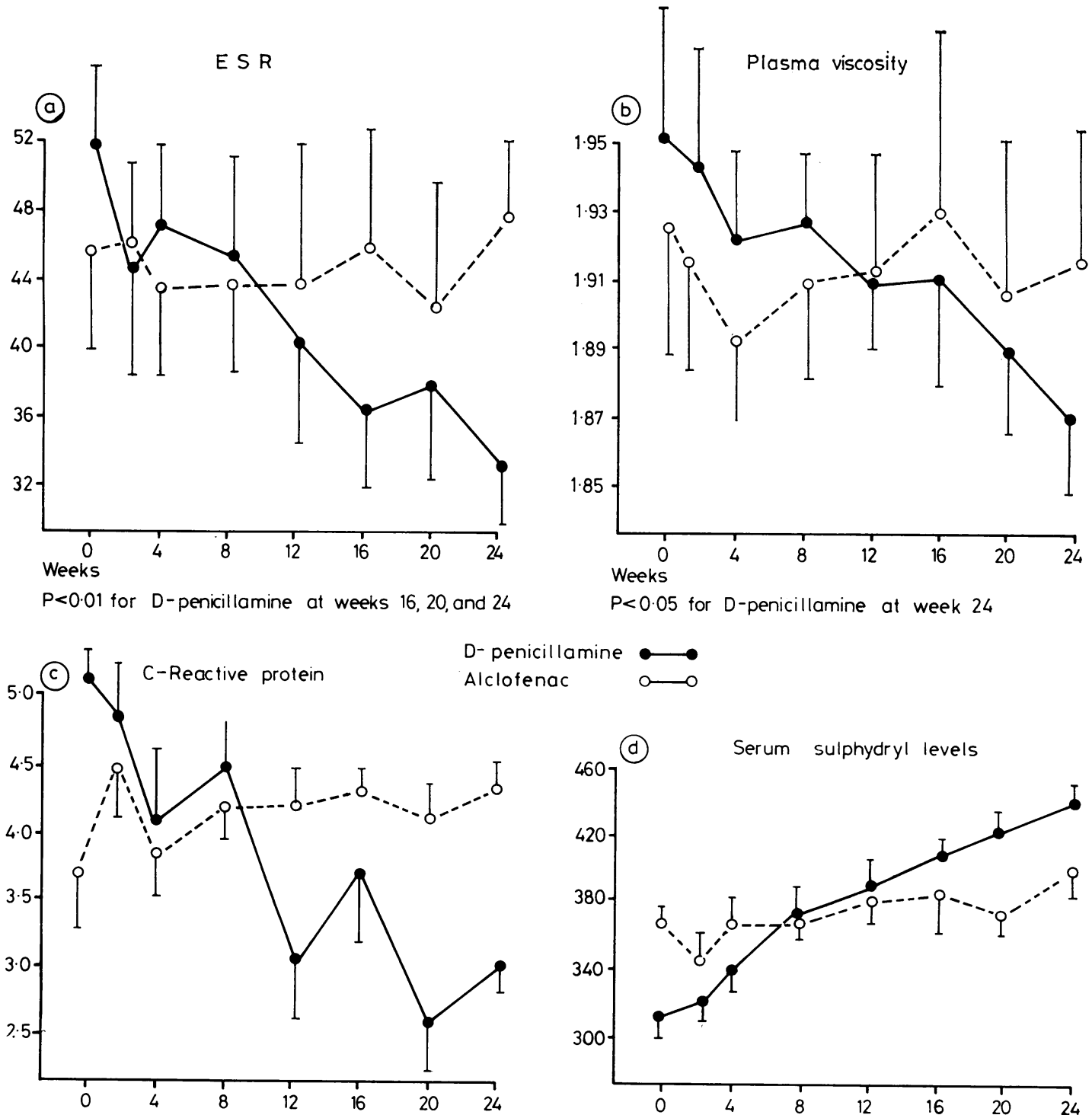

Weeks

$P<0.01$ for $D$ - penicillamine at weeks $12,16,20$, and 24

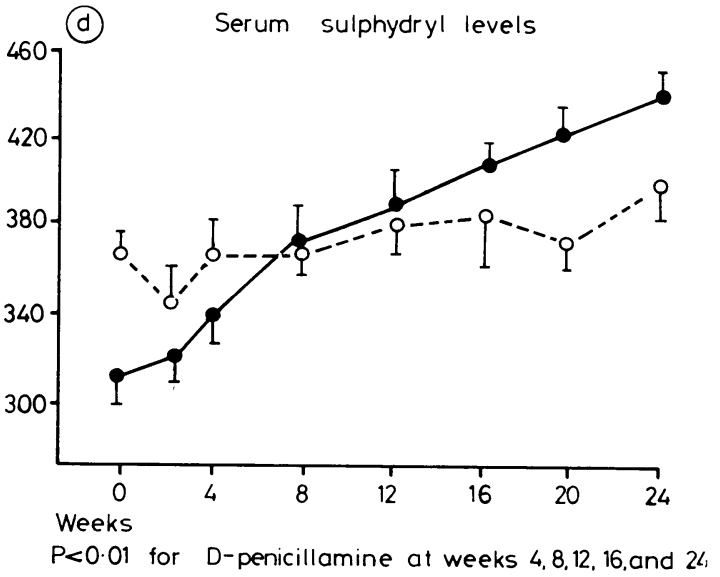

Fig. 1 Serial changes in 30 patients treated either with alclofenac or D-penicillamine for (a) ESR, (b) plasma viscosity, (c) C-reactive protein, (d) total serum sulphydryl level. Vertical lines denote standard error of the mean. Changes in individual parameters reaching statistical significance when compared with data at week 0 are indicated (Wilcoxon rank sum). 
The majority of clinical variables showed improvement with D-penicillamine, not seen with alclofenac This was most marked with articular index, which showed a significant improvement by week 16 $(P<0.01)$ and thereafter, whereas change with alclofenac did not show significant improvement. Change in summated change scale was also marked on D-penicillamine, though grip strength showed little change on either drug.

A striking difference was also observed between the 2 correlation matrices (Tables 1 and 2). Levels of significance for D-penicillamine were not only of higher order but also more frequently seen than those obtained with alclofenac.

\section{Discussion}

Although we are reluctant to draw clinical conclusions from a study in which entry was not strictly randomised, this study suggests that alclofenac did not produce the long-term clinical benefit seen with D-penicillamine. The high drop-out rate in the alclofenac treated group prevented satisfactory statistical between-group comparison towards the end of the study. Nevertheless, it appears that mean patient data for the relatively small alclofenac group remained approximately constant instead of showing the steady serial change seen with D-penicillamine.

Our study failed to confirm some of the biochemical

Table 1 Correlation matrices between clinical and biochemical variables for D-penicillamine. $P$ values represent the degree of significance of correlation between mean clinical and biochemical data at each clinic visit

\begin{tabular}{|c|c|c|c|c|c|c|c|c|}
\hline \multirow[t]{2}{*}{ Systemic parameters } & \multicolumn{8}{|c|}{ Clinical parameters } \\
\hline & $\begin{array}{l}\text { Articular } \\
\text { index }\end{array}$ & $\begin{array}{l}\text { Joint } \\
\text { size }\end{array}$ & $\begin{array}{l}\text { Summated } \\
\text { change } \\
\text { scale }\end{array}$ & $\begin{array}{l}\text { Aspirin } \\
\text { dose }\end{array}$ & $\begin{array}{l}\text { Early } \\
\text { morning } \\
\text { stiffness }\end{array}$ & $\begin{array}{l}\text { Grip } \\
\text { strength }\end{array}$ & $\begin{array}{l}\text { Pain } \\
\text { score }\end{array}$ & $\begin{array}{l}\text { Functional } \\
\text { grade }\end{array}$ \\
\hline Sulphydryl & 0.001 & 0.01 & 0.001 & 0.001 & 0.05 & 0.01 & 0.01 & 0.05 \\
\hline Viscosity & 0.001 & 0.001 & 0.001 & 0.01 & 0.01 & 0.05 & 0.01 & 0.05 \\
\hline Platelets & 0.001 & 0.001 & 0.001 & 0.01 & 0.05 & 0.05 & 0.05 & 0.05 \\
\hline Bilirubin & 0.001 & 0.01 & 0.01 & 0.001 & 0.05 & 0.01 & 0.05 & - \\
\hline CR protein & 0.001 & 0.01 & 0.01 & 0.05 & 0.01 & 0.05 & 0.05 & 0.05 \\
\hline ESR & 0.01 & 0.01 & 0.01 & 0.01 & 0.05 & 0.05 & 0.05 & 一 \\
\hline Albumin & 0.01 & 0.01 & 0.05 & 0.05 & 0.05 & 0.05 & - & - \\
\hline Haptoglobin & 0.05 & 0.05 & 0.05 & 0.05 & 0.01 & 0.05 & - & - \\
\hline GGTP & 0.01 & 0.01 & 0.05 & 0.05 & - & 0.05 & - & - \\
\hline Haemoglobin & - & - & 0.05 & 0.05 & - & 0.05 & - & 0.05 \\
\hline Alk. phos. & - & 0.01 & 0.05 & - & 0.05 & 0.05 & - & - \\
\hline Fibrinogen & 0.05 & - & 一 & 0.05 & 一 & 一 & 0.05 & - \\
\hline Creatinine & 一 & 一 & - & - & 0.05 & - & - & - \\
\hline Histidine & 一 & 一 & 一 & - & 一 & 0.05 & - & - \\
\hline Protein & 0.05 & 0.05 & - & - & - & - & - & - \\
\hline WBC & - & - & - & - & - & - & 0.05 & - \\
\hline SGOT & 一 & - & - & - & - & - & - & - \\
\hline Globulin & - & - & 一 & - & - & - & - & - \\
\hline
\end{tabular}

Table 2 Correlation matrices between clinical and biochemical variables for alclofenac. $P$ values represent the degree of significance of correlation between mean clinical and biochemical data at each clinic visit

\begin{tabular}{|c|c|c|c|c|c|c|c|c|}
\hline \multirow[t]{2}{*}{ Systemic parameters } & \multicolumn{8}{|c|}{ Clinical parameters } \\
\hline & $\begin{array}{l}\text { Articular } \\
\text { index }\end{array}$ & $\begin{array}{l}\text { Joint } \\
\text { size }\end{array}$ & $\begin{array}{l}\text { Summated } \\
\text { change } \\
\text { scale }\end{array}$ & $\begin{array}{l}\text { Aspirin } \\
\text { dose }\end{array}$ & $\begin{array}{l}\text { Early } \\
\text { morning } \\
\text { stiffness }\end{array}$ & $\begin{array}{l}\text { Grip } \\
\text { strength }\end{array}$ & $\begin{array}{l}\text { Pain } \\
\text { score }\end{array}$ & $\begin{array}{l}\text { Functional } \\
\text { grade }\end{array}$ \\
\hline Sulphydryl & 一 & - & - & - & - & - & - & - \\
\hline Viscosity & - & - & - & - & 一 & 0.05 & - & - \\
\hline Platelets & - & - & 0.05 & - & - & - & - & - \\
\hline Bilirubin & 一 & - & - & - & - & - & - & - \\
\hline CR protein & - & - & - & - & - & - & - & - \\
\hline ESR & - & - & - & - & - & - & 0.05 & - \\
\hline Albumin & 一 & - & - & - & - & - & 0.01 & 一 \\
\hline Haptoglobin & - & - & 一 & 一 & - & - & - & - \\
\hline GGTP & 一 & - & 一 & - & - & - & 一 & - \\
\hline Haemoglobin & - & - & 0.01 & 0.05 & - & - & - & - \\
\hline Alk. phes. & 0.05 & - & - & - & - & - & - & - \\
\hline Fibrinogen & - & - & - & - & - & - & - & - \\
\hline Creatinine & - & - & - & - & - & - & 一 & - \\
\hline Histidine & - & - & - & - & - & - & - & - \\
\hline Protein & - & - & - & - & - & - & - & - \\
\hline WEC & - & - & 0.01 & - & - & - & - & 0.01 \\
\hline SGOT & 0.05 & - & - & 0.05 & - & 一 & - & - \\
\hline Globulin & 一 & - & - & - & - & - & 0.01 & - \\
\hline
\end{tabular}


changes reported previously with alclofenac. One possible explanation is that our study differs from those previously reported, both in excluding patients who had previously received penicillamine-like drugs and in excluding concurrent medication other than aspirin.

If a drug has a fundamental action on the disease process it would be reasonable to expect simultaneous improvement in both clinical and biochemical parameters and thus a significant correlation between them. Comparison of correlation matrices for different drugs is therefore a meaningful screen on small groups of patients for possible longterm antirheumatoid activity in novel compounds. Moreover, it will not be biased by patient drop-out. It is, however, necessary to confirm that the compound under test does not make the disease significantly worse. A clear difference emerges between the correlation matrices for these 2 drugs, and our unpublished data on comparable matrices obtained from patients treated with hydroxychloroquine and gold support the validity of this comparative approach. On this basis, as well as on review of the observed clinical and biochemical changes, we have found no evidence over a 6-month period to support the view that alclofenac has a specific antirheumatoid effect. Moreover patient tolerance of this drug was poorer than for D-penicillamine.

We thank Mr J. R. Lowe and Miss A. Saunders for technical assistance, Mrs V. M. Rhind and Mrs P. A. Leatham for clinical assessments, and Mrs D. K. Smith for typing the script. We acknowledge the financial support of Roche
Products Ltd. and thank Dr D. Galloway for helpful discussion and $\mathrm{Mr} \mathrm{C}$. Hallett for statistical advice.

AdDENDUM: Alclofenac was discontinued by the manufacturers (Berk) on 29 June 1979.

\section{References}

1 Maddock J, Rees P, Holly F, Aylward M. The influence of alclofenac treatment on acute phase proteins, plasma tryptophan and erythrocyte sedimentation rate in patients with rheumatoid arthritis. Curr Med Res Opin $1975 ; 3$ : 286-297.

2 Berry H, Fernandes L, Ford-Hutchinson A W, Evans S J W, Hamilton E B D. Alclofenac and D-penicillamine. Ann Rheum Dis 1978; 37: 93-97.

3 Aylward M. Clinical studies on alclofenac in the treatment of rheumatic diseases: a drug in question. Curr Med Res Opin 1975; 3: 274-285.

4 Evans P H. Serum sulphydryl levels in rheumatoid patients treated with alclofenac. Curr Med Res Opin 1975; 3: 268-273.

5 Ritchie D M, Boyle J A, McInnes J M, Jasani M K, Dalakos T G, Grieveson P, Buchanan W W. Clinical studies with an articular index for the assessment of joint tenderness in patients with rheumatoid arthritis. $Q J$ Med 1968; 37: 393-406.

6 Harkness J. The viscosity of human blood plasma: its measurement in health and disease. Biorheology 1971; 8: $171-193$

7 Crockson R A. A gel-diffusion precipitin method for estimation of C-reactive protein. J Clin Path 1963; 16: 287-289.

8 Gerber D A, Cohen N, Giustra R. The ability of nonsteroid anti-inflammatory compounds to accelerate a disulphide interchange reaction of serum sulphydryl groups and 5, 5'-Dithiobis (2-nitrobenzoate). Biochem Pharmacol 1967; 16: 115-123.

9 Rhind V M, Bird H A, Wright V. A comparison of clinical assessments of disease activity in rheumatoid arthritis. Ann Rheum Dis 1979; in press. 